九州大学学術情報リポジトリ

Kyushu University Institutional Repository

Thermostabilization of Modified Enzymes by Amidination with Dimethylsuberimidate or by Combination of Enzyme-dextran Conjugate with Hexame thy lenediamine

Matsumoto, Kiyoshi

Laboratory of Food Quality Control, Faculty of Agriculture, Kyushu University

Miyazaki, Eiji

Laboratory of Food Quality Control, Faculty of Agriculture, Kyushu University

Osajima, Yutaka

Laboratory of Food Analysis, Faculty of Agriculture, Kyushu University

https://doi.org/10.5109/24043

出版情報：九州大学大学院農学研究院紀要. 38 (1/2)，pp.111-117，1993-12. Kyushu University バージョン：

権利関係: 
J. Fac. Agr., Kyushu Univ., 38 (1•2), 111-117 (1993)

\title{
Thermostabilization of Modified Enzymes by Amidination with Dimethylsuberimidate or by Combination of Enzyme-dextran Conjugate with Hexamethylenediamine
}

\author{
Kiyoshi Matsumoto, Eiji Miyazaki* and Yutaka Osajima** \\ Laboratory of Food Quality Control, Faculty of Agriculture, \\ Kyushu University 46-09, Fukuoka 812, Japan \\ **Laboratory of Food Analysis, Faculty of Agriculture, \\ Kyushu University 46-09, Fukuoka 812, Japan \\ (Received July 30, 1993)
}

\begin{abstract}
The thermostabilization of some enzymes by amidination with dimethylsuberimidate was surveyed. In the enzymes investigated, a moderate increase of thermostability in glucose oxidase and invertase, and prominent increase in lactate dehydrogenase, alcohol dehydrogenase and ascorbate oxidase were observed. The increase of thermostability by amidination was suggesting the synergism of the enhancement of intersubunit salt bridges and the conformational stabilization by intra- and intermolecular cross-linking. The coupling of oxidized dextran with periodate on the surface of the enzyme molecule (enzyme-dextran-conjugate) and the subsequent cross-linking with hexamethylenediamine were also proposed to enhance the thermostability. A moderate increase of thermostability was observed for catalase, ascorbate oxidase, lactate dehydrogenase and alcohol dehydrogenase and a prominent increase was observed for diaphorase, $\alpha$-chymotripsin, glucose oxidase and invertase. Enhanced thermostabilities of enzymes may be attributed to the mild procedure of the preparation of enzyme-dextran-conjugate, the introduction of polyol structure on or around the surface of enzyme molecule and the intramolecular cross-linking with hexamethylenediamine.
\end{abstract}

\section{INTRODUCTION}

Enzymes are remarkably good catalysts in terms of their catalytic activity, selectivity, and ability to function under mild conditions. So, enzymes are employed in the production of pharmaceuticals, in bioreactors of food and chemical industries, and in chemical and clinical analyses.

Enzymes, however, are lacking in stability. Consequently, the utilization of enzymes is limited. The stabilization of enzymes is an important goal to increase the utility of them, and has received much attention in recent years.

There are two main techniques to get stabilized enzymes. One is a biological technique which includes the screening of the thermophilic microoganisms or the development of a thermostable gene by gene manipulation. Another is a chemical modification of enzymes (Klivanov, 1983). Although some thermostable enzymes produced by biological techniques have been reported, the number is limited at this time. The stabilization of enzymes by a chemical modification, therefore, is required to compensate for the biological technique.

It is well established in the literature that rigidification of native structure leads to stabilization of the enzymes, particularly against thermal inactivation. One of the

*Present Address: Nisshin Flour Co. Ltd., 
impressive results for rigidification of native enzyme structure has been obtained by cross-linking with bifunctional reagents.

Amidination is a selective procedure for the $\varepsilon$-amino groups of the lysines in proteins and does not change the charge (Tuengler and Pfleiderer, 1977). Acetamidination has been reported to lead to enhanced heat, alkaline and triptic stability of pig heart lactate dehydrogenase. In this paper, the thermostabilization of some enzymes by amidination with dimethylsuberimidate is surveyed.

Another increase of thermal resistance has been observed for enzymes immobilized on soluble supports such as polysaccharides (dextran, CM-cellulose, and DEAEdextran) or synthetic polymers.

J.-P. Lenders and R. R. Crichton (1984) have succeeded in preparing several soluble thermostable enzymes by covalent coupling to a soluble polysaccharide. The coupling of polysaccharide on the surface of an enzyme molecule seems to be effective for the thermostabilization of enzymes.

In the present study we propose to combine the coupling technique of polysaccharide on enzyme with the cross-linking technique of intra- or intermolecule of the coupled enzymes.

\section{MATERIALS AND METHODS}

\section{Reagents}

Alcohol dehydrogenase (ADH, EC 1.1.1.1, from yeast), lactate dehydrogenase (LDH, EC 1.1.1.27, from pig heart), and $\beta$-nicotinamide adenine dinucleotide (reduced form, $\beta$ $\mathrm{NADH}$ ) were perchased from Oriental Yeast Co., Ltd. (Tokyo). Glucose oxidase (GOD, EC 1.1.3.4, from Aspergillus niger), $\alpha$ - chymotripsin (EC 3.4.21.1, from bovine pancreas), and dextran T70 were perchased from Sigma Chemical Co. (MO, USA). Catalase (EC 1.11.1.6, from bovine liver, Type I ) and invertase (EC 1.6.99, from microorganism, T-06) were from Toyo Jozo Co. (Shizuoka). $\beta$-nicotinamaide adenine dinucleotide (oxidized form, $\beta-\mathrm{NAD}$ ) was from Kohjin Co., Ltd. (Tokyo). Dimethyl suberimidate hydrochloride (DMS), sodium periodate and sodium cyanoborohydride were from Nakarai Tesque Co. (Kyoto). Hexamethylenediamine dihydrochloride was from Tokyo Kasei Ind. (Tokyo). Other chemicals were of reagent grade and used without purification.

\section{Apparatus}

The spectrophotometer used was a Simadzu UV-300 and the thermostat used was a Colora Cryothermostat EK5. The high performance liquid chromatograph (HPLC) used was Tosoh CCPM-pump and UV-8000 detector. The column was TSK gel DEAE$5 \mathrm{PW}(7.5 \mathrm{~mm} \times 7.5 \mathrm{~mm})$.

\section{Activity Measurements}

The activities of $\mathrm{ADH}$ and $\mathrm{LDH}$ were measured by monitoring the increase of the absorbance of NADH at $340 \mathrm{~nm}$ (Manual of Oriental Yeast Co., 1984). The activity of GOD was measured by the o-dianisidine-peroxidase method (Manual of Oriental Yeast Co., 1984). The activity of ASOD was measured by monitoring the decrease of the 
absorbance of ascorbic acid at $265 \mathrm{~nm}$ (Manual of Oriental Yeast Co., 1984). The activity of diaphorase was measured by the 2,6- dichlorophenolindophenol method (Manual of Oriental Yeast Co., 1984). The activity of catalase was measured by monitoring the decrease of the absorbance of hydrogen peroxide at $240 \mathrm{~nm}$ (Aebi, 1983). Activity of invertase was determined by measuring reducing sugar by 3,5dinitrosalicylic acid method. The activity of $\alpha$ - chymotripsin was measured spectrophotometrically by using $\mathrm{N}$-succinyl ${ }^{-\mathrm{L}^{-}}$phenylalanie -nitroanilide as a substrate (Geiger, 1984).

\section{Amidination of Enzymes}

Ten $\mathrm{mg}$ of each enzyme were dissolved in $1 \mathrm{ml}$ of $0.2 \mathrm{M}$ pyrophosphate buffer ( $\mathrm{pH}$ 9.0). To the enzyme solution $6 \mathrm{mg}$ of dimethylsuberimidate was added which was dissolved in $1 \mathrm{ml}$ of $1 \mathrm{M}$ triethanol amine $(\mathrm{pH} 9.0$ ) prior to use. The reaction mixture was stirred for $1 \mathrm{~h}$ at $20^{\circ} \mathrm{C}$. Then, the mixture was dialyzed completely against $10 \mathrm{mM}$ pyrophosphate buffer $\left(\mathrm{pH} \mathrm{9.0)}\right.$ at $5^{\circ} \mathrm{C}$.

\section{Modification of Enzyme with Activated Dextran}

Dextran T70 (300 mg) was dissolved in $6 \mathrm{ml}$ of deionized water. To the solution was added $400 \mathrm{mg}$ of sodium periodate and reacted for $75 \mathrm{~min}$ at room temperature under constant stirring. When the effect of periodate concentration was investigated, 400, 240, 120 and $30 \mathrm{mg}$ of iodate were used, respectively. The reaction mixture was dialyzed for $4 \mathrm{~h}$ against deionized water by changing water every hour. To the solution $(0.5 \mathrm{ml})$ of the activated dextran thus obtained were added $0.5 \mathrm{ml}$ of each enzyme solution $(2 \mathrm{mg} / \mathrm{ml}$ ) prepared by $0.2 \mathrm{M}$ buffer solution and $8 \mathrm{mg}$ of sodium cyanoborohydride. After the mixture was reacted for $16 \mathrm{~h}$ at $5{ }^{\circ} \mathrm{C}, 0.35 \mathrm{ml}$ of hexamethylenediamine (HMDA, $200 \mathrm{mg} / \mathrm{ml}$ ) or glycine (GLY, $250 \mathrm{mg} / \mathrm{ml}$ ) was added in order to stop the enzyme -dextran coupling reaction, and reacted further for $3 \mathrm{~h}$. Each dextran - modified enzyme was sufficiently dialyzed against $10 \mathrm{mM}$ of each specified buffer at $5^{\circ} \mathrm{C}$. The modified enzymes which were blocked with HMDA and GLY were denoted as Conjugate (HMDA) and Conjugate (GLY), respectively.

\section{Separation of invertase-dextran-conjugate by HPLC}

The dialysis tube containing enzyme-dextran-conjugate was put on a petri dish and covered with polythyleneglycol flakes at $5{ }^{\circ} \mathrm{C}$ and the content of the tube was concentrated to the volume of $0.5 \mathrm{ml}$. The concentrate of enzyme-dextran-conjugate thus obtained was subjected to HPLC equipped with TSK gel DEAE-5PW. The elution was performed by linear gradient with (A) $0.02 \mathrm{M}$ sodium acetate buffer. ( $\mathrm{pH} \mathrm{5.0)}$ ) and (B) $0.02 \mathrm{M}$ sodium acetate buffer ( $\mathrm{pH} \mathrm{5.0)}$ containing $0.5 \mathrm{M}$ sodium chloride for $60 \mathrm{~min}$. The flow rate, injection volume, and detection wave length were $1.0 \mathrm{ml} / \mathrm{min}, 0.5 \mathrm{ml}$ and $280 \mathrm{~nm}$, respectively. The fraction of the enzyme-dextran-conjugate was collected on the basis of absorbance larger than 0.03 at $280 \mathrm{~nm}$. Then, the eluate was concentrated

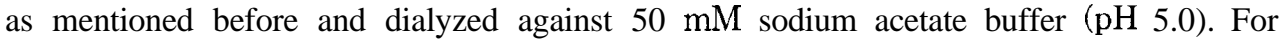
enzme-dextran-conjugate thus obtained, protein concentration, amount of amino groups and aldehyde groups, and heat resistivity were measured. 


\section{Measurement of Thermal Resistance of Enzymes}

The native and modified enzyme solutions (100 $\mu 1$ each) were taken into test tubes and heated in a thermostated bath at a specific temperature for 30 and $60 \mathrm{~min}$. The treated solutions were imediately cooled in an ice bath. The test solutions were put back to room temperature and the activities of them were measured as described above. The thermostabilities of native enzymes were measured at $1 \mathrm{mg} / \mathrm{ml}$ concentration level in order to allow the thermoproperties of enzymes prominent.

\section{Other Measurements}

The determination of amino-group was performed by the method of Habeeb (1966). The determinations of total sugar and aldehyde - group were made by the phenol sulfuric acid method and the 3,5-dinitrosalcylic acid method, respectively. The protein assay was performed according to the manual of the Bio Rad protein assay kit.

\section{RESULTS AND DISCUSSION}

\section{Amidination of Enzymes}

One of the general approaches to thermostabilization of enzymes could be a replacement of lysine (or histidine) by arginine in the hope of enhancing intramolecular or intersubunit salt bridges. Amidination has been introduced as a selective procedure for the $\varepsilon$-amino groups of the lysines in proteins. Amidinated lysine, then, has a homoarginine-like structure, producing an increase of $\mathrm{pK}$ - value of lysine residue (Means and Feenery, 1971; Hunter and Ludwig, 1972). In this experiment, bisimidate, DMS, was selected as an amidination agent in order to enhance the strength of the intersubunit salt bridges and also to stabilize the conformation of enzyme by intra- and intermolecular cross-linking.

The thermostabilities of amidinated enzymes are shown in Table 1. When LDH was selected to explain the figures of Table 1, each figure in the table is denoted as below. After native $\mathrm{LDH}$ was heated at $60^{\circ} \mathrm{C}$ for $30 \mathrm{~min}$ in an incubator, the activity of $\mathrm{LDH}$ was reduced to $15.9 \%$ from the original (native 100\%). On the other hand, the amidination procedures, themselves, reduced the $\mathrm{LDH}$ - activity to $66.2 \%$ from the original (native 100\%). The amidinated $\mathrm{LDH}$, however, acquired heat resistivity, and remained $81.1 \%$ of its activity even after heat treatment for $30 \mathrm{~min}$. The figure $(53.7 \%)$ in parenthesis indicates the products of $66.2 \%$ and $81.1 \%$, that means overall residual activity converted from the original activity (native 100\%). The last column, in the same way, indicates the results of heat treatment for $60 \mathrm{~min}$. In the enzymes investigated, moderate increases of thermostability in GOD and invertase, and prominent increase in LDH, ADH and ASOD were observed, as shown in Table I . The increase of thermostability by amidination shown above is suggesting the synergism of the enhancement of intersubunit salt bridges and the conformational stabilization by intra - and intermolecular cross - linking. However, the restricted species of enzymes (LDH, ASOD) showed a prominent increase of thermostability since amidination is a relatively severe procedure and it requires a favorable steric position between amino group and carboxyl group for the stabilization of comformation by electrostatic combination in the enzyme molecule. 
Table 1. Thermostability of amidinated enzymes with dimethysuberimidate.

\begin{tabular}{|c|c|c|c|c|}
\hline Enzyme species & $\begin{array}{l}\text { Residual activity } \\
\text { after modification }\end{array}$ & $\begin{array}{l}\text { Temp. } \\
\left({ }^{\circ} \mathrm{C}\right)\end{array}$ & $\begin{array}{l}\text { Residual activity } \\
\text { after heating } \\
30 \mathrm{~min}\end{array}$ & $60 \mathrm{~min}$ \\
\hline \multicolumn{5}{|l|}{ LDH } \\
\hline Native & 100 & 60 & 15.9 & 5.5 \\
\hline Amidinated & 66.2 & 60 & $81.1(53.7)$ & $72.3(47.9)$ \\
\hline \multicolumn{5}{|l|}{ ASOD } \\
\hline Native & 100 & 50 & 2.2 & 1.8 \\
\hline Amidinated & 74.0 & 50 & $58.4(43.2)$ & $60.2(44.5)$ \\
\hline \multicolumn{5}{|l|}{ Diaphorase } \\
\hline Native & 100 & 60 & 68.9 & 47.4 \\
\hline Amidinated & 60.2 & 60 & $56.4(34.0)$ & $19.1(11.5)$ \\
\hline \multicolumn{5}{|l|}{$\mathrm{ADH}$} \\
\hline Native & 100 & 50 & 1.0 & 0.2 \\
\hline Amidinated & 29.3 & 50 & $66.2(19.4)$ & $60.1(17.6)$ \\
\hline \multicolumn{5}{|l|}{ GOD } \\
\hline Native & 100 & 60 & 4.2 & 3.4 \\
\hline Amidinated & 93.1 & 60 & $18.6(17.3)$ & $14.9(13.9)$ \\
\hline \multicolumn{5}{|l|}{ Invertase } \\
\hline Native & 100 & 60 & 19.3 & 7.0 \\
\hline Amidinated & 21.5 & 60 & $39.1(8.4)$ & $31.1(6.7)$ \\
\hline \multicolumn{5}{|l|}{$\alpha$-Chymotripsin } \\
\hline Native & 100 & 50 & 12.6 & 11.2 \\
\hline Amidinated & 34.3 & 50 & $8.0(2.7)$ & $5.1(1.8)$ \\
\hline \multicolumn{5}{|l|}{ Catalase } \\
\hline Native & 100 & 60 & 16.2 & 7.2 \\
\hline Amidinated & 27.2 & 60 & $2.9(0.8)$ & $1.8(0.5)$ \\
\hline
\end{tabular}

\section{Enzyme-D extran-Conjugates}

Table 2 shows the thermostabilities of enzyme-dextran-conjugates. The meanings of each figure in the table is the same as Table 1. As shown in Table 2, an increase of thermostability was observed for all enzymes investigated. The thermostabilities of conjugate (HMDA) in GOD, invertase and diaphorase were much larger than those of conjugates (GLY). The bifunctional agent, HMDA, may retain the dextran moiety uniformly on the surface of an enzyme molecule by cross-linking between amino groups on the enzyme molecule and the unreacted aldehyde groups on dextran. To ensure the effect of the oxidizing agent (iodate) and the number of polyol introduced, the invertase - dextran - conjugate prepared with a different concentration of iodate was separated from unreacted free dextran by HPLC and the number of glucose units introduced on the surface of enzyme were measured with respect to its thermoresistivity. Table 3 shows the results for investigating the effect of the ratio of oxidizing agent (iodate) to polysaccharide (dextran), the quantity of the aldehyde groups present by measure of the reducing power and the quantity of amino groups on the thermoresistivity of invertase. The increase of the ratio of oxidizing agent to polysaccharide (from No. 1 to No. 4) produced the increase of the quantity of the aldehyde group. On the other hand, the amino groups introduced per mg -enzyme 
Table 2. Thermostability of enzyme-dextran Conjugates,

\begin{tabular}{|c|c|c|c|c|c|}
\hline \multirow[t]{2}{*}{ Enzyme species } & \multirow[t]{2}{*}{$\begin{array}{l}\text { Residual activity } \\
\text { after modification }\end{array}$} & \multirow[t]{2}{*}{$\begin{array}{l}\text { Temp. } \\
\left({ }^{\circ} \mathrm{C}\right)\end{array}$} & \multicolumn{3}{|c|}{$\begin{array}{r}\text { Residual activity } \\
\text { after heating }\end{array}$} \\
\hline & & & $30 \mathrm{~min}$ & $60 \mathrm{mi}$ & \\
\hline Native & 100 & 60 & 4.2 & & 3.4 \\
\hline Conjugate (GLY) & 86.1 & 60 & $20.0(17.2)$ & 8.9 & (7.6) \\
\hline Conjugate (HMDA) & 57.2 & 60 & $74.6(42.8)$ & 69.0 & $(39.5)$ \\
\hline \multicolumn{6}{|l|}{ Invertase } \\
\hline Native & 100 & 60 & 19.3 & & 7.6 \\
\hline Conjugate (GLY) & 61.2 & 60 & $34.7(21.2)$ & 25.9 & $(15.9)$ \\
\hline Conjugate (HMDA) & 39.5 & 60 & $76.1(30.1)$ & 62.2 & (24.6) \\
\hline \multicolumn{6}{|l|}{ Catalase } \\
\hline Native & 100 & 60 & 16.2 & & 7.2 \\
\hline Conjugate (GLY) & 46.2 & 60 & $43.1(19.9)$ & 25.9 & $(12.0)$ \\
\hline Conjugate (HMDA) & 38.5 & 60 & $40.6(15.6)$ & 25.1 & $(9.7)$ \\
\hline \multicolumn{6}{|l|}{ ASOD } \\
\hline Native & 100 & 50 & 2.2 & & 1.8 \\
\hline Conjugate (GLY) & 1.0 & 50 & $100.0(1.0)$ & 100.0 & $(1.0)$ \\
\hline Conjugate (HMDA) & 25.7 & 50 & $49.5(12.7)$ & 41.2 & (10.6) \\
\hline \multicolumn{6}{|l|}{$\alpha$-Chymotripsin } \\
\hline Native & 100 & 50 & 12.6 & & 11.2 \\
\hline Conjugate (GLY) & 6.8 & 50 & $100.0(6.8)$ & 79.1 & (5.4) \\
\hline Conjugate (HMDA) & 13.4 & 50 & $80.5(10.8)$ & 83.5 & $(11.2)$ \\
\hline \multicolumn{6}{|l|}{ Diaphorase } \\
\hline Native & 100 & 60 & 68.9 & & 47.4 \\
\hline Conjugate (GLY) & 17.9 & 60 & $48.6(8.7)$ & 42.9 & (7.7) \\
\hline Conjugate (HMDA) & 6.5 & 60 & $80.8(5.3)$ & 84.9 & (5.5) \\
\hline \multicolumn{6}{|l|}{ LDH } \\
\hline Native & 100 & 60 & 15.9 & & 5.5 \\
\hline Conjugate (GLY) & 9.0 & 60 & $54.8(5.0)$ & 55.1 & $(5.0)$ \\
\hline \multicolumn{6}{|l|}{$\mathrm{ADH}$} \\
\hline Native & 100 & 50 & 1.0 & & 0.2 \\
\hline Conjugate (GLY) & 3.5 & 50 & $47.5(1.7)$ & 18.2 & $(0.6)$ \\
\hline Conjugate (HMDA) & 2.6 & 50 & $27.2(0.7)$ & 3.2 & $(0.1)$ \\
\hline
\end{tabular}

protein were almost constant, regardless of the amount of oxidizing agent. Consequently, the number of glucose units introduced per mg-enzyme protein or $\mathrm{m}$ mol of amino group increased from No. 1 to No. 4, in spite of the modification of dextran with the same molecular weight. The thermoresistivity of invertase - dextran -conjugate also increased with increasing the number of glucose units introduced. This suggests that the difference of the structurization of the water molecule occurred in relation to the amount of polyol on or around the surface of enzyme molecule. Enhanced thermostabilities of enzymes may be attributed to (1) the mild procedure of the preparation of enzyme-dextran-conjugate, (2) the introduction of polyol structure on or around the surface of the enzyme molecule, causing the selective hydration on the surface of the enzyme molecule and stabilization with hydrophobic interaction of enzyme protein via structurization of the water molecule and (3) the intramolecular 
Thermostabilization of modified enzymes by amidination with dimethylsuberimidate or by combination of enzyme-de\&an conjugate with hexamethylenediamine

Table 3. Properties of invertase-dextran-conjugates.

\begin{tabular}{|c|c|c|c|c|c|c|c|}
\hline No. & $\begin{array}{c}\text { Molecular ratio } \\
\mathrm{NaIO}_{4} / \text { glucose } \\
\text { unit }\end{array}$ & $\begin{array}{c}\text { Reducing } \\
\text { power* }\end{array}$ & $\begin{array}{l}\text { Modified } \\
\text { amino group } \\
\text { (A) } \\
\text { m mol } \\
\text { /mg protein }\end{array}$ & $\begin{array}{l}\text { Bound } \\
\text { p glucose } \\
\text { (B) } \\
\mathrm{mg} \\
\text { /mg p }\end{array}$ & $\begin{array}{l}\text { Introduced } \\
\text { unit glucose unit } \\
(\mathrm{B} / \mathrm{A}) \\
\mathrm{mg} \\
\text { rotein } / \mathrm{m} \mathrm{mol}\end{array}$ & \multicolumn{2}{|c|}{\begin{tabular}{cc}
\multicolumn{2}{c}{ Residual activity } \\
after & heating \\
$30 \mathrm{~min}$ & $60 \mathrm{~min}$ \\
$\%$ & $\%$
\end{tabular}} \\
\hline Native & $\ldots$ & $\ldots$ & $\ldots$ & $\ldots$ & $\ldots$ & 19.3 & 7.5 \\
\hline 1 & 0.075 & 0.24 & 0.19 & 0.07 & 0.37 & 19.8 & 8.8 \\
\hline 2 & 0.3 & 0.84 & 0.21 & 0.10 & 0.48 & 21.3 & 9.9 \\
\hline 3 & 0.6 & 1.33 & 0.21 & 0.31 & 1.5 & 21.8 & 13.9 \\
\hline 4 & 1.0 & 1.60 & 0.20 & 2.6 & 13 & 31.0 & 18.7 \\
\hline
\end{tabular}

*This is expressed as m mol of maltose equivalent per gram of oxidized dextran (T70).

cross-linking.

The most preferable procedure for the preparation of thermostable enzymes seems to be the introduction of relatively long -chain polyol containing many hydroxyl groups and the intramolecular cross-linking which maintain polyol uniformly on the surface of enzymes.

\section{REFERENCES}

Aebi, H. E. 1983 Catalase In "Methods of Enzymatic Analysis," 3rd ed., vol. 3, ed. by H. U. Bergmeyer, Verlag Chemie GmbH, Weinheim, 273-286.

Geiger, R. $1984 \alpha$-Chymotripsin In "Methods in Enzymatic Analysis," 3rd ed., Vol. 5, ed. by H. U. Bergmeyer, Verlag Chemie GmbH, Weinheim, 99 -109.

Habeeb, A. F. S. 1966 Determination of Free Amino Groups in Proteins by Trinitrobenzenesulfonic Acid. Anal. Biochem., 14: 328-336.

Hunter, M. J. and M. L. Ludwig 1972 Amidination. In "Methods in Enzymology," Vol. 25, ed. by C. H. W. Hirs and S. N. Timasheff, Academic Press, New York, San Francisco, London, 585596.

Klivanov, A. M. 1983 Stabilization of Enzymes Against Thermal Inactivation. Adv. Appl. Microbiol., 29: 1-28.

Lenders, J. -P. and R. R. Crichton 1984 Thermal Stabilization of Amylolytic Enzymes by Covalent Coupling to Soluble Polysaccharides. Biotechn. Bioeng., 26: 1343 -1351.

Oriental Yeast Co., In "Biochemicals 1982 -1984," 9-64.

Tuengler, P. and G. Pfleiderer 1977 Enhanced Heat, Alkaline and Tryptic Stability of Acetamidinated Pig Heart Lactate Dehydrogenase. Biochim. Biophys. Acta, 484: 1-8. 